\title{
Mode I Critical Stress Intensity Factor of Medium- Density Fiberboard Obtained by Single-Edge- Notched Bending Test
}

\section{Faktor kritičnog intenziteta naprezanja (I. mod) MDF ploča dobiven testom savijanja}

\author{
Original scientific paper • Izvorni znanstveni rad \\ Received-prispjelo: 6. 4. 2013. \\ Accepted-prihvaćeno: 6. 2. 2014. \\ UDK: $630 * 863.312 ; 630 * 812.71 ; 674.817$ \\ doi:10.5552/drind.2014.1326
}

\begin{abstract}
The Mode I critical stress intensity factor $\left(K_{I c}\right)$ obtained by single-edge-notched bending (SENB) tests of medium-density fiberboard (MDF) was experimentally analyzed. In the SENB test, the critical load for crack propagation $\left(P_{c}\right)$ was determined from the relationship between load/loading-line displacement and load/crack opening displacement (COD). A double cantilever beam (DCB) test was also conducted and the results were compared with those of SENB tests. The value of Mode I critical stress intensity factor was obtained by introducing an additional crack length, when the crack length ranged from 0.5 to 0.7 times the depth of the specimen. This range coincided well with that used to derive the appropriate $K_{I c}$ value in the single-edge-notched tension (SENT) test, which was conducted using the specimens with a similar configuration cut from the MDF panel used in this study.
\end{abstract}

Key words: additional crack length, Mode I critical stress intensity factor, medium-density fiberboard (MDF), western hemlock, single-edge-notched bending (SENB) test

\begin{abstract}
SAŽETAK • U radu se eksperimentalno analizira faktor kritičnog intenziteta naprezanja (I. mod) ( $\left.K_{I c}\right)$ dobiven testom savijanja s jednim rubnim urezom (SENB) za ploče vlaknatice srednje gustoće (MDF ploče). U SENB testu kritično opterećenje za širenje pukotine $\left(P_{c}\right)$ određeno je iz odnosa opterećenja i linije pomaka te iz odnosa opterećenja i širenja pukotine (COD). Proveden je i dvostruki konzolni test (DCB), a rezultati su uspoređeni s rezultatima SENB testova. Vrijednost faktora kritičnog intenziteta naprezanja (I. mod) dobiven je uvođenjem dodatne duljine pukotine kada je duljina pukotine u rasponu od 0,5 do 0,7 debljine uzorka. Taj se raspon podudario s rasponom koji se koristi za dobivanje odgovarajuće $K_{I C}$ vrijednosti u tenzijskom testu s jednim rubnim urezom (SENT), a proveden je na uzorcima slične konfiguracije izrađenima od MDF ploče koja je upotrijebljena i u ovom istraživanju.
\end{abstract}

Ključne riječi: dodatna duljina pukotine, faktor kritičnog intenziteta naprezanja (I. mod), ploče vlaknatice srednje gustoće (MDF), test savijanja s jednim rubnim urezom (SENB test)

\footnotetext{
Authors are professors at Faculty of Science and Engineering, Shimane University, Matsue, Shimane, Japan.

Autori su profesori Fakulteta prirodoslovlja i inženjerstva, Shimane sveučilište, Matsue, Shimane, Japan.
} 


\section{INTRODUCTION}

\section{UVOD}

In analyzing the fracture behavior of material based on fracture mechanics theory, the value of critical stress intensity factor $K_{c}$ is often measured because it can be regarded as a material constant. Of the three independent fracture modes, the crack opening mode (Mode I) is regarded as more important than the inplane shear mode (Mode II) and out-of-plane shear mode (Mode III) because the Mode I critical stress intensity factor $\left(K_{\mathrm{Ic}}\right)$ is usually smaller than those of Mode II and Mode III, $K_{\mathrm{IIc}}$ and $K_{\mathrm{IIIc}}$, respectively. To determine the $K_{\text {Ic }}$ value, single-edge-notched bending (SENB), single-edge-notched tension (SENT), compact tension (CT), and double cantilever beam (DCB) tests, the diagrams of which are shown in Figures 1(a)(d), respectively, are most frequently performed because the crack propagation under the opening mode can be easily induced by these tests.

In previous works, the $K_{\mathrm{Ic}}$ value of medium-density fiberboard (MDF) was examined by SENT and CT tests (Yoshihara, 2010b; Yoshihara and Usuki, 2011). In these tests, we found that the $K_{\text {Ic }}$ value of MDF can be effectively measured when considering the additional crack length ahead of the crack tip and restricting the range of initial crack length with respect to the specimen geometry. Nevertheless, these tests require attachments to apply the tensile load, so the use of the attachments often restricts the specimen geometry. The SENB test is attractive because it can be conducted using specimens with various geometries more easily than the SENT and CT tests (Yoshihara, 2010a).

In this study, we examined the $K_{\text {Ic }}$ value of MDF by the SENB test using two types of specimens with different dimensions. The results were compared with those obtained from the DCB tests, which can be determined based on energy consideration and are mathematically well defined (Adams et al., 2003).

\section{MATERIALS AND METHODS} 2. MATERIJALI I METODE

\subsection{Materials}

2.1. Materijali

An MDF panel, which was used in previous works (Yoshihara, 2010b; Yoshihara and Usuki, 2011), was investigated. The density of the MDF at $12 \%$ moisture content $(M C)$ was $580 \pm 10 \mathrm{~kg} / \mathrm{m}^{3}$. The panel was stored in a room at a constant $20^{\circ} \mathrm{C}$ and $65 \%$ relative humidity $(R H)$ before the test, and the specimens were confirmed to be in an air-dried state. These conditions were maintained throughout the tests. Five specimens were tested for each test condition.

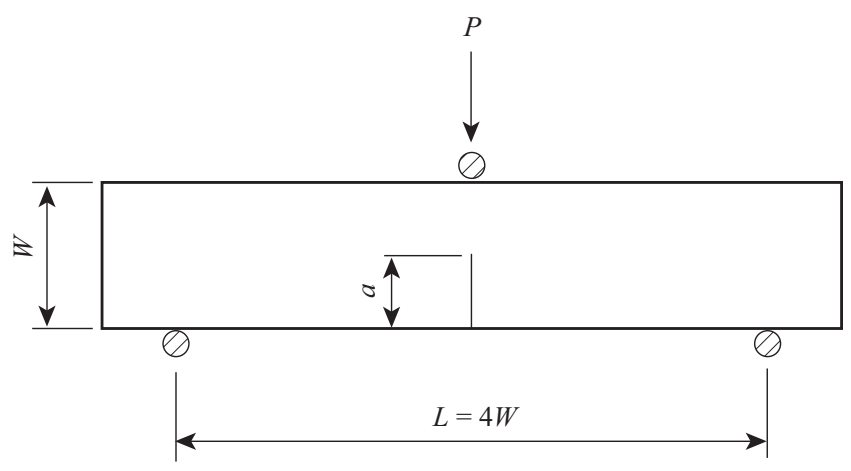

(a) SENB test

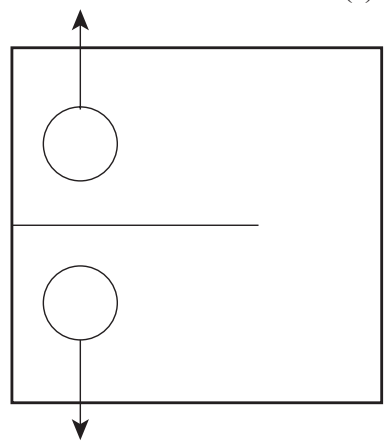

(c) CT test

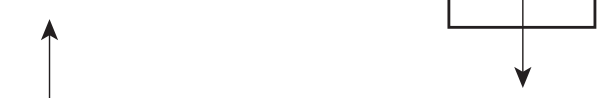

(b) SENT test

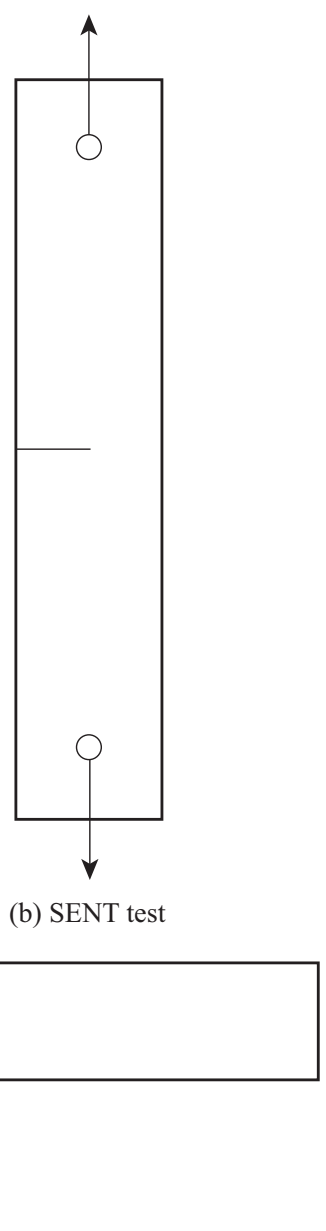

(d) DCB test

Figure 1 Typical Mode I fracture tests Slika 1. Tipični testovi loma drva I. moda 


\subsection{SENB tests}

\subsection{SENB testovi}

Figure 1(a) shows the diagram of the SENB test. Two kinds of specimens were tested. Specimen A had dimensions of $20 \times 90 \times 15 \mathrm{~mm}^{3}$, while these dimensions were $40 \times 180 \times 15 \mathrm{~mm}^{3}$ in specimen $\mathrm{B}$. The specimen depth $W$ was 20 and $40 \mathrm{~mm}$ in specimens A and $\mathrm{B}$, respectively. The crack was first cut with a band saw (thickness $=1 \mathrm{~mm}$ ) and then extended $1 \mathrm{~mm}$ ahead of the crack tip with a razor blade. The crack length $a$ varied from 1 to $18 \mathrm{~mm}$ at intervals of $1 \mathrm{~mm}$ in specimen A, and from 2 to $36 \mathrm{~mm}$ at intervals of $2 \mathrm{~mm}$ in specimen B. Thus, the value of $a / W$ varied from 0.1 to 0.9 at intervals of 0.1 . The specimen configurations were similar with those of SENB tests for western hemlock (Yoshihara, 2010a).

In the SENB test of western hemlock, the nonlinearity in the relationship between the load $(P)$ and loading-line deflection $(\delta)$ was not significant until the initiation of crack propagation, so the critical load for crack propagation was determined as the maximum load (Yoshihara, 2010a). From the results of the SENT and CT tests of MDF in which the crack opening displacement $(C O D)$ was measured, the nonlinearity was marked in the $P-C O D$ relationship (Yoshihara, 2010b; Yoshihara and Usuki, 2011). Although the loading-line displacement in the SENB test is significantly larger than that in the SENT and CT tests, we thought that the measurement of the $C O D$ was effective to detect the nonlinearity and $\delta$. To measure the $C O D$, a clip gauge extensometer (capacity $=5 \mathrm{~mm}$; UB-5, Tokyo Sokki, Co., Tokyo, Japan) was used. The specimen was symmetrically supported and loaded at the mid-span. The span lengths $(L)$ were 80 and $160 \mathrm{~mm}$ in specimens A and $\mathrm{B}$, respectively, giving an $L / W$ value of 4 . A steel platen was placed between the specimen and the support to reduce indentation at the supporting point. The load $P$ was applied at a crosshead speed of $0.5 \mathrm{~mm} /$ $\min ^{1}$ until the load markedly decreased. The total testing time was approximately $5 \mathrm{~min}$.

Figure 2 shows typical $P-\delta$ and $P-C O D$ relationships obtained by the SENB tests. In the results for western hemlock, the crack often propagates unstably when the initial crack length is less than 0.3 times the depth of the specimen, whereas it propagates stably when the initial crack is longer than 0.4 times the depth (Yoshihara, 2010a). In the results of MDF, however, the crack always propagates stably all over the range of the initial crack length. In addition, the $P-\delta$ and $P-C O D$ relationships were significantly nonlinear before the load reached its maximum. Therefore, the critical load for crack propagation $P_{\mathrm{c}}$ was provisionally determined to be the load at the onset of nonlinearity. This was determined in the same manner as that used for the SENT and CT tests (Yoshihara, 2010b; Yoshihara and Usuki, 2011) and for the DCB tests described below.

Similar to the previous investigation (Yoshihara $2010 \mathrm{a}$ ), the $K_{\mathrm{Ic}}$ value was initially evaluated using the following two equations, which were originally proposed by Gross and Srawley (1965) and Srawley (1976):

$$
\begin{array}{r}
K_{\mathrm{Ic}}=\frac{3 \cdot P_{\mathrm{c}} \cdot L}{2 \cdot B \cdot W^{2}} \cdot \sqrt{\pi \cdot a} \cdot\left[1.09-1.735 \cdot\left(\frac{a}{W}\right)+8.20 \cdot\left(\frac{a}{W}\right)^{2}-14.18 \cdot\left(\frac{a}{W}\right)^{3}+14.57 \cdot\left(\frac{a}{W}\right)^{4}\right] \\
K_{\mathrm{Ic}}=\frac{3 \cdot P_{\mathrm{c}} \cdot L}{2 \cdot B \cdot W^{2}} \cdot \sqrt{\pi \cdot a} \cdot\left[\frac{1.99-\left(\frac{a}{W}\right) \cdot\left(1-\frac{a}{W}\right) \cdot\left[2.15-3.93 \cdot\left(\frac{a}{W}\right)+2.7 \cdot\left(\frac{a}{W}\right)^{2}\right]}{\sqrt{\pi} \cdot\left[1+2 \cdot\left(\frac{a}{W}\right)\right] \cdot\left[1-\frac{a}{W}\right]^{\frac{3}{2}}}\right]
\end{array}
$$

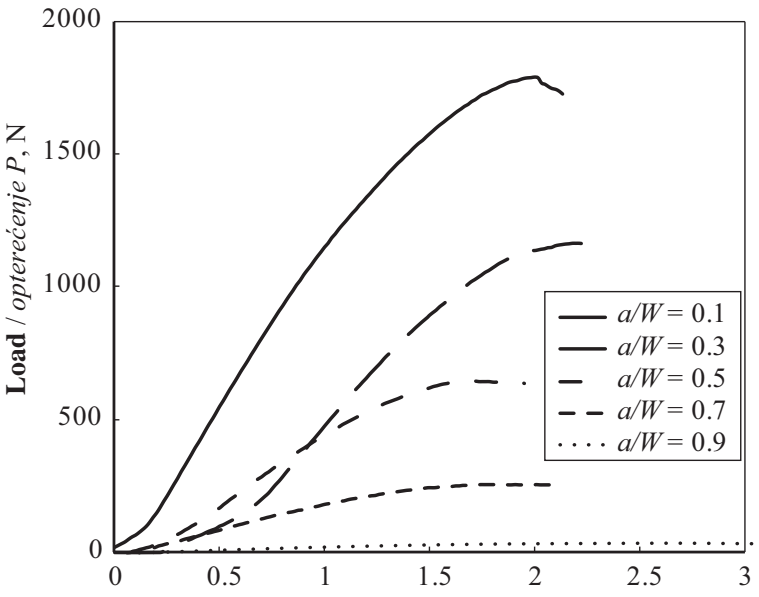

Loading-line displacement / pomak linije opterećenja $\delta$, mm

where $B$ is the beam width.

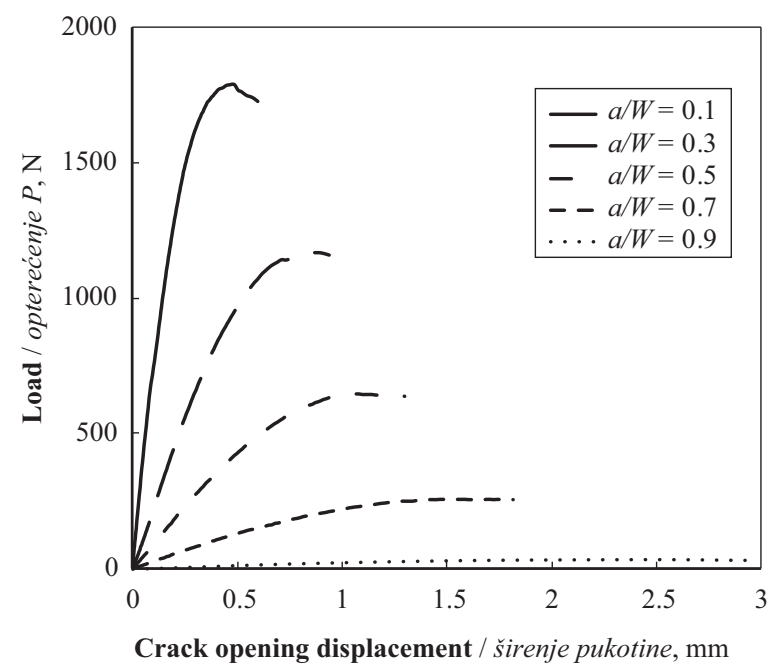

Figure 2 Typical example of the relationship between load $P$ and loading-line displacement $\delta$ and that between $P$ and the crack opening displacement $C O D$ for various crack lengths $a$ in SENB test. Depth of the specimen $W=40 \mathrm{~mm}$ Slika 2. Tipičan primjer odnosa između opterećenja $P$ i pomaka linije opterećenja $\delta$ te između opterećenja $P$ i širenja pukotine $C O D$ za različite duljine pukotine $a$ u SENB testu; debljina uzorka $W=40 \mathrm{~mm}$ 


\subsection{DCB tests}

\subsection{DCB test}

The $K_{\mathrm{Ic}}$ value was measured by the DCB test using a side-grooved specimen independent of the SENB test, and it was compared with those obtained from the SENB test. The details of the DCB test were similar to those previously conducted (Yoshihara, 2010a, b).

\section{RESULTS AND DISCUSSION} 3. REZULTATI I RASPRAVA

Figure 3 shows the $K_{\mathrm{Ic}}-a / W$ relationships obtained from the SENB tests using Eqs. (1) and (2) and a comparison of these relationships with the results obtained by the DCB tests. A convex trend was identified in these relationships. This trend is different from that obtained by the SENB tests of western hemlock. That trend was almost constant in the $a / W$ range of $0.1-0.7$ and 0.1-0.9 when using Eqs. (1) and (2), respectively (Yoshihara, 2010a). The $K_{\mathrm{Ic}}$ value obtained from specimen $\mathrm{A}$ is larger than that from specimen $\mathrm{B}$ when com- paring the same $a / W$ value, except for $a / W=0.1$, so the $K_{\text {Ic }}$ values obtained from Eqs. (1) and (2) are regarded to be dependent on the specimen geometry. The point at the onset of nonlinearity, the load at which it was provisionally defined as the critical load for crack propagation $P_{\mathrm{c}}$, could be found earlier in the $P-C O D$ relationship than in the $P-\delta$ relationship. Therefore, the $K_{\text {Ic }}$ value obtained from the $P-C O D$ relationship is smaller than that obtained from the $P-\delta$ relationship.

Figure 3 suggests that the $K_{\mathrm{Ic}}$ values obtained using Eq. (1) and (2) are definitively smaller than that obtained by the DCB test because the development of a softened region ahead of the crack tip, such as fracture process zone (FPZ), is not taken into account in these equations. Due to the softened region, the cracked specimen often behaves as if the crack were longer than the actual length. Similar to the approach adopted in previous investigations (Yoshihara, 2010a, b; Yoshihara and Usuki, 2011), the relationship between $K_{\text {Ic }}$ and $a$ is modified by introducing an additional crack length $\Delta$ into Eqs. (1) and (2) as follows:
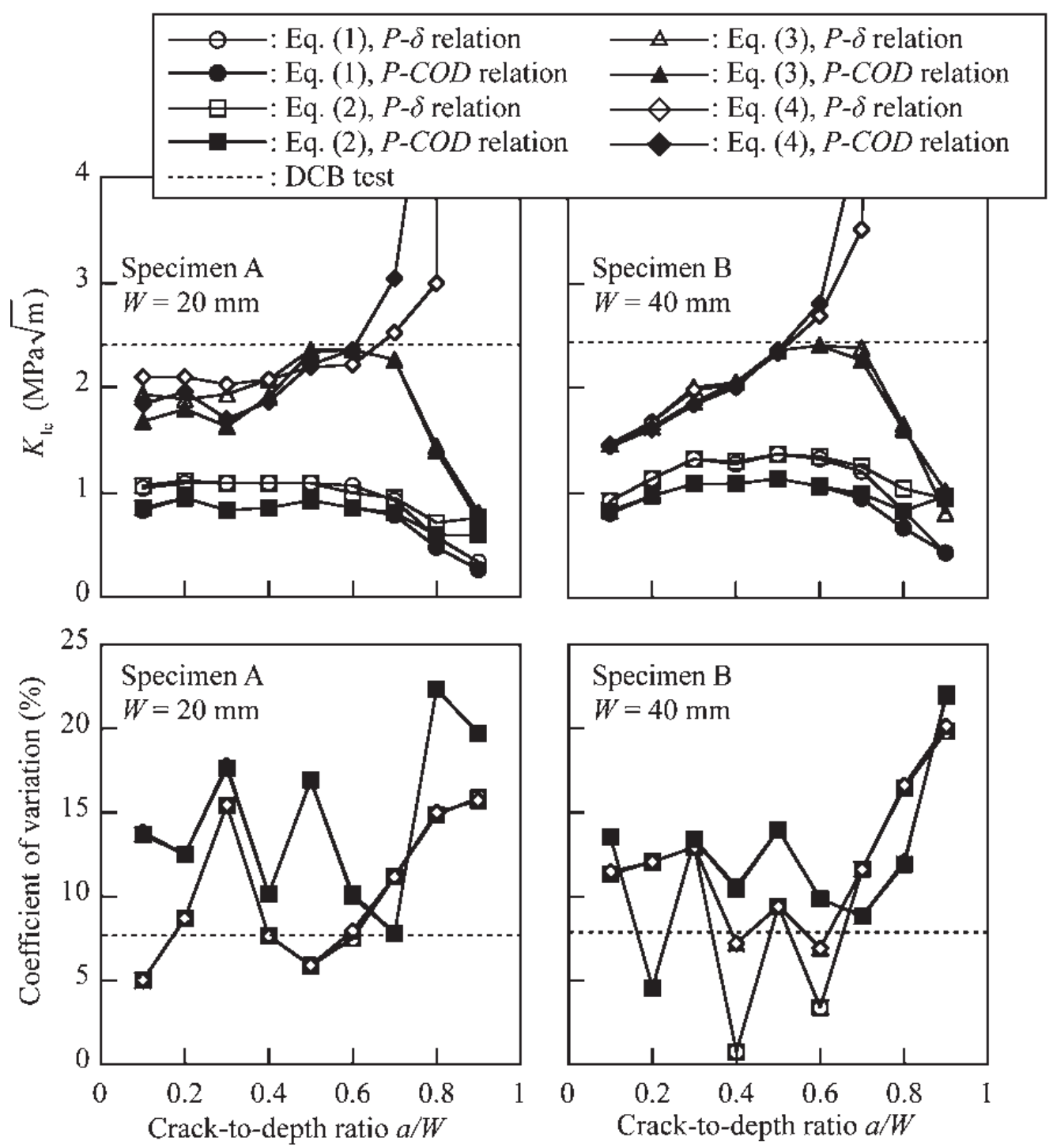

Figure 3 Comparison of the relationships between $K_{\mathrm{Ic}}$ and $a / W$ obtained by SENB test and that obtained by DCB test

Slika 3. Usporedba odnosa između $K_{\mathrm{Ic}}$ i $a / W$ dobivenoga SENB testom i DCB testom 


$$
K_{\mathrm{Ic}}=\frac{3 \cdot P_{\mathrm{c}} \cdot L}{2 \cdot B \cdot W^{2}} \cdot \sqrt{\pi \cdot(a+\Delta)} \cdot\left[1.09-1.735 \cdot\left(\frac{a+\Delta}{W}\right)+8.20 \cdot\left(\frac{a+\Delta}{W}\right)^{2}-14.18 \cdot\left(\frac{a+\Delta}{W}\right)^{3}+14.57 \cdot\left(\frac{a+\Delta}{W}\right)^{4}\right]
$$
and

$$
K_{\mathrm{Ic}}=\frac{3 \cdot P_{\mathrm{c}} \cdot L}{2 \cdot B \cdot W^{2}} \cdot \sqrt{\pi \cdot(a+\Delta)}\left[\frac{1.99-\left(\frac{a+\Delta}{W}\right) \cdot\left(1-\frac{a+\Delta}{W}\right) \cdot\left[2.15-3.93 \cdot\left(\frac{a+\Delta}{W}\right)+2.7 \cdot\left(\frac{a+\Delta}{W}\right)^{2}\right]}{\sqrt{\pi} \cdot\left[1+2 \cdot\left(\frac{a+\Delta}{W}\right)\right] \cdot\left[1-\frac{a+\Delta}{W}\right]^{\frac{3}{2}}}\right]
$$

The appropriate value of additional crack length $\Delta$ was determined from the following procedure, which was similar to those conducted in previous studies (Yoshihara, 2010a, b; Yoshihara and Usuki, 2011). By altering the value of $\Delta$, the probability value ( $p$-value) for the averages of $K$ Ic obtained by the SENB test corresponding to each $a / W$ and DCB test is calculated by Student's $t$-test. Then the $p$-values corresponding to each $\Delta$ are summed up. When the amount of the $p$-values is large, the average values of $K \mathrm{Ic}$ obtained by the SENB and DCB tests can be regarded as being close to each other. The $\Delta$ value was obtained by binary search algorithm as shown in Table 1. The $\Delta$ values listed in Table 1 are longer than those of western hemlock, which were 2 and $4 \mathrm{~mm}$ for specimen $\mathrm{A}$ and $\mathrm{B}$, respectively (Yoshihara, 2010a).

Table 1 Additional crack length $\Delta$ derived by statistically comparing $K_{\mathrm{Ic}}$ values obtained from SENB and DCB tests (unit $=\mathrm{mm}$ )

Tablica 1. Dodatna duljina pukotine $\Delta$ dobivena statističkom usporedbom vrijednosti $K_{\mathrm{Ic}}$ ustanovljene SENB testom i DCB testom (jedinica mm)

\begin{tabular}{|c|c|c|c|}
\hline \multirow{2}{*}{$W$} & \multirow{2}{*}{$\begin{array}{c}\text { Equation } \\
\text { Jednadžba }\end{array}$} & \multicolumn{2}{|c|}{ Relationship / Odnos } \\
\cline { 3 - 4 } & $(3)$ & $P-\delta$ & $P-C O D$ \\
\hline 20 & $(4)$ & 4.1 & 4.8 \\
\hline 20 & $(3)$ & 6.1 & 5.7 \\
\hline 40 & $(4)$ & 5.9 & 7.9 \\
\hline 40 & & 7.6 \\
\hline
\end{tabular}

The $\Delta$ value obtained from the $P-C O D$ relationship is larger than that obtained from the $P-\delta$ relationship. Figure 3 also shows the results calculated by Eqs. (3) and (4). The values of $K_{\mathrm{Ic}}$ obtained from Eq. (3) are close to those obtained by the DCB tests when $a / W$ falls in the approximate range of 0.5 to 0.7 . A statistical analysis of the difference between the $K_{\mathrm{Ic}}$ values obtained using the SENB and DCB tests shows that the difference is not significant in this $a / W$ range, regardless of whether the $P_{\mathrm{c}}$ value is determined from the $P-\delta$ or $P-C O D$ relationship. This range coincides well with the range used to derive the appropriate $K_{\mathrm{Ic}}$ value in the SENT test (Yoshihara 2010b). When using Eq. (4), however, the applicable range of $a / W$ is narrower than that obtained using Eq. (3). When the $a / W$ value is smaller than 0.4 , material nonlinearity precedes the crack propagation, so the load at the onset of nonlinearity in the $P-\delta$ and $P-C O D$ relationships $P$ cannot be regarded as the critical load for crack propagation
(Yoshihara 2010b). Therefore, the $K_{\mathrm{Ic}}$ values for $a / W$ values smaller than 0.4 were measured to be smaller than those in the $a / W$ range from 0.5 to 0.7 . In contrast, the value of $K_{\mathrm{Ic}}$ calculated from Eq. (3) decreases in the $a / W$ range larger than 0.8 , whereas that calculated from Eq. (4) diverges when $a / W$ exceeds 0.8 because the value of $1-(a+\Delta) / W$ contained in the equation is close to zero. Therefore, the $K_{\mathrm{Ic}}-a / W$ relationships obtained from Eqs. (3) and (4) are extremely different from each other when the value of $a / W$ exceeds 0.8 . Additionally, when the crack tip is close to the loading point, the compressive stresses due to the indentation of the loading nose hinder self-similar crack propagation (de Moura et al., 2010). From these reasons, the appropriate range for introducing the additional crack is restricted. From the results obtained here, the $K_{\text {Ic }}$ value should be measured using Eq. (3) in the $a / W$ range from 0.5 to 0.7 .

In this research, the additional crack length $\Delta$ is determined by statistically comparing the $K_{\mathrm{Ic}}$ values obtained from the $P-\delta$ and $P-C O D$ relationships and that obtained by the DCB test. Therefore, the $\Delta$ value is dependent on the relationship used in the analysis, as shown in Table 1. Based on the concept of the FPZ, however, the value of $\Delta$ can be physically obtained (Vasic and Smith, 2002; Vasic et al., 2003; Morel et al., 2003; 2005; de Moura et al., 2008, 2010; Dourado et al., $2008,2010)$. As shown in Figure 2 , the $K_{\mathrm{Ic}}$ values obtained from both $P-\delta$ and $P-C O D$ relationships are similar to each other when correcting the crack length. Therefore, it is difficult to determine which relationship is more valid for determining the $K_{\mathrm{Ic}}$ value. Microscopic observation (Vasic and Smith, 2002; Vasic et al., 2003) and digital image correlation observation (Murata et al., 2011) around the crack tip during loading may be effective to reveal the validity of the relationships.

According to the research on the Mode II critical stress intensity factor $K_{\text {IIC }}$ of wood and MDF as determined by an asymmetric four-point bending test, the $K_{\text {IIc }}$ value can be obtained by introducing the additional crack length when $a / W$ exceeds 0.8 , when an appropriate equation is derived for the crack geometry factor (Yoshihara submitted). In the SENB tests of solid wood (Yoshihara, 2010a) and MDF, two previously proposed equations (Eqs. (1) and (2)) were used and modified by considering the additional crack length. Further research should be conducted to find a new equation that can derive the $K_{\mathrm{Ic}}$ value properly for the specimen with an $a / W$ value larger than 0.8 . In addition, the compressive stresses due to the indentation of the loading nose 
can be reduced when conducting the four-point SENB (4SENB) test in which the loading-line deviates from the crack pass, and the range of $a / W$ can be extended. Therefore, further research should also be conducted on the 4SENB test of MDF and solid wood.

\section{CONCLUSIONS \\ 4. ZAKLJUČAK}

A single-edge-notched bending (SENB) test of MDF was conducted to obtain the Mode I critical stress intensity factor $K_{\mathrm{Ic}}$. The test results were compared with those of the double cantilever beam (DCB) tests, an approach that is thought to be valid because the $K_{\text {Ic }}$ value can be determined based on energy considerations.

The above results are interpreted to indicate that the critical stress intensity factor $K_{\mathrm{Ic}}$ in Mode I can be obtained effectively by introducing the additional crack length $\Delta$ as in Eq. (3) under the range of the crack length/specimen depth ratio $a / W$ from 0.5 to 0.7 . This range coincided well with that obtained in the singleedge-notched tension (SENT) tests of MDF Yoshihara, 2010b). To determine the value of $K_{\text {Ic }}$ under a wide range of $a / W$, further research should be undertaken on issues such as additional crack lengths, other equations for determining the $K_{\text {Ic }}$ value, and other test methods including the four-point SENB (4SENB) test.

\section{Acknowledgement - Zahvala}

This work was supported in part by a Grant-inAid for Scientific Research (C) (No. 21580207) from the Japan Society for the Promotion of Science (JSPS).

\section{REFERENCES}

\section{LITERATURA}

1. Adams, D. F.; Carlsson, L. A.; Pipes, R. B., 2003: Experimental Characterization of Advanced Composites Materials. 3rd edition, Boca Raton: CRC Press

2. De Moura, M. F. S. F.; Morais, J. J. L.; Dourado, N., 2008: A new data reduction scheme for mode I wood fracture characterization using the double cantilever beam test. Engineering Fracture Mechanics 75 (13): 3852-3865. http://dx.doi.org/10.1016/j.engfracmech.2008.02.006

3. De Moura, M. F. S. F.; Dourado, N.; Morais, J. J. L., 2010: Crack equivalent based method applied to wood fracture characterization using the single edge notchedthree point bending test. Engineering Fracture Mechanics 77 (3): 510-520.

http://dx.doi.org/10.1016/j.engfracmech.2009.10.008

4. Dourado, N.; Morel, S.; de Moura, M. F. S. F.; Valentin, G.; Morais, J., 2008: Comparison of fracture properties of two wood species through cohesive crack simulations.
Composites Part A: Applied Science and Manufacturing 39 (2): 415-427.

http://dx.doi.org/10.1016/j.compositesa.2007.08.025

5. Dourado, N. M. M.; de Moura, M. F. S. F.; Morais, J. J. L.; Silva, M. A. L., 2010: Estimate of resistance-curve in wood through the double cantilever beam test. Holzforschung 64 (1): 119-126. http://dx.doi.org/10.1515/hf.2010.010

6. Morel, S.; Bouchaud, E.; Schmittbuhl, J., 2003: Influence of the specimen geometry on R-curve behavior and roughening of fracture surfaces. International Journal of Fracture 121 (1-2): 23-42.

http://dx.doi.org/10.1023/A:1026221405998

7. Morel, S.; Dourado, N.; Valentin, G.; Morais, J., 2005: Wood: a quasibrittle material R-curve behavior and peak load evaluation. International Journal of Fracture 131 (4): 385-400. http://dx.doi.org/10.1007/s10704-004-7513-0

8. Murata, K.; Nagai, H.; Nakano, T., 2011: Estimation of width of fracture process zone in spruce wood by radial tensile test. Mechanics of Materials 43 (7): 389-396. http://dx.doi.org/10.1016/j.mechmat.2011.04.005

9. Vasic, S.; Smith, I., 2002: Bridging crack model for fracture of spruce. Engineering Fracture Mechanics 69 (6): 745-760. http://dx.doi.org/10.1016/S0013-7944(01)00091-1

10. Vasic, S.; Smith, I.; Landis, E., 2003: Fracture zone characterization. Micro-mechanical study. Wood and Fiber Science 34 (1): 42-56.

11. Yoshihara, H., 2010a: Examination of the mode I critical stress intensity factor of wood obtained by single-edgenotched bending test. Holzforschung 64 (4): 501-509. http://dx.doi.org/10.1515/hf.2010.083

12. Yoshihara, H., 2010b: Influence of loading conditions on the measurement of mode I critical stress intensity factor for wood and medium-density fiberboard by the singleedge-notched tension test. Holzforschung 64 (6): 735-745. http://dx.doi.org/10.1515/hf.2010.119

13. Yoshihara, H.; Usuki, A., 2011: Mode I critical stress intensity factor of wood and medium-density fibreboard measured by compact tension test. Holzforschung 65 (5): 729-735. http://dx.doi.org/10.1515/hf.2011.063

14. Yoshihara, H., 2013: Mode II critical stress intensity factor of medium-density fiberboard measured by asymmetric four-point bending tests and analyses of kink crack formation. BioResources 8 (2): 1771-1789.

\section{Corresponding address:}

Professor HIROSHI YOSHIHARA, Ph.D.

Shimane University

Faculty of Science and Engineering

Nishikawazu-cho 1060

Matsue, Shimane 690-8504, JAPAN

e-mail: yosihara@riko.shimane-u.ac.jp 